Bayero Journal of Pure and Applied Sciences, 5(2): 148 - 155

Received: September 2012

Accepted: December 2012

ISSN $2006-6996$

\title{
EFFECTS OF WEED CONTROL AND COW DUNG MANURE ON GROWTH INDICES OF QUALITY PROTEIN MAIZE
}

Mahadi, M. A., Dadari, S. A., Tanimu, B., Kuchinda, N. C., Sharifai, A. I. and Bature, M. S. Department of Agronomy, Faculty of Agriculture/Institute for Agricultural Research Ahmadu Bello University, Zaria, Nigeria

\section{ABSTRACT}

Field trials were conducted during the 2006, 2007 and 2008 rainy seasons at the Institute for Agricultural Research farm Samaru, in the Northern guinea savanna zone of Nigeria to evaluate the effects of weed control and cow dung manure treatments on growth of quality protein maize. The trials consisted of factorial combinations of eight weed control treatments which include application of proprietary mixtures of (Atrazine + Acetochlor + Terbuthylazine at a ratio of 1:1:1, Atrazine + Metolachlor at a ratio of $1: 2$ each at 3.0 and $4.0 \mathrm{~kg}$ a.i/ha, Atrazine at 4.0 and $5.0 \mathrm{~kg}$ a.i/ha, Hoe weeded at 3 and 6 weeks after sowing and a weedy check) with four cow dung manure levels at $(0,4,8$ and $12 \mathrm{t} / \mathrm{ha}$ and a recommended NPK mineral fertilizer check at the rate of $120 \mathrm{~kg}$ $N, 26 \mathrm{~kg} P$ and $50 \mathrm{~kg} \mathrm{~K} / \mathrm{ha}$. The treatments were laid out in a split plot design with three replicates. Results indicated that application of Atrazine + Metolachlor at $4.0 \mathrm{~kg}$ a.i/ha and the two hoe weeded produced significantly (p>0.05) higher and similar values of 140.2 and 137.3 grams respectively for total dry matter with 11.1 and $11.8 \mathrm{~g} / \mathrm{m}^{2} /$ week respectively for crop growth rate. Plots treated with Atrazine + Metolachlor at $4.0 \mathrm{~kg}$ a.i/ha recorded significantly the highest values of 3.05 for leaf area index and 0.41 for harvest index. Application of Atrazine + Acetochlor + Terbuthylazine at $4.0 \mathrm{~kg}$ a.i/ha significantly recorded the highest shoot lodging count. The highest relative growth rate was by plots treated with Atrazine + Metolachlor at $3.0 \mathrm{~kg}$ a.i/ha. The weedy check consistent/y produced the least values for all parameters. Application of cow dung manure at $12 t / h a$ and the NPK mineral fertilizer check significantly produced the highest values for all parameters while the least were by the 0 fertilizer control. Based on the result of this study it can be concluded that the application of Atrazine + Metolachlor at $4.0 \mathrm{~kg} \mathrm{a.i/ha}$ and cow dung manure at 12 t/ha significant/y increased growth indices of Quality Protein Maize.

Keywords - Weed control, Cow dung manure, Growth indices, Quality protein maize

\section{INTRODUCTION}

Maize (Zea mays L.) is one of the most important staple food crops in west and central Africa. The savanna zone of west and central Africa has the greatest potential for its production, due to relatively high incidence of solar radiation and lower incidence of pest and diseases during the cropping season (Badu-Apraku et al., 2006). According to Food and Agricultural Organization of the United Nations, 822.7 million metric tonnes of maize were produced worldwide in the year 2008 on 159.5 million hectares. The United States of America produced 333 million metric tonnes, china produced 163 million metric tonnes, Latin America and the Caribbean produced 84 million metric tonnes, Africa produced 53.2 million metric tonnes, while Nigeria produced only 7.5 million metric tonnes (FAO, 2008).

Maize is widely believed to have the greatest potential among food crops for attaining technological breakthroughs that will improve food production in the savanna zone of west and central Africa (Kamara and Sanginga, 2001). Quality Protein Maize (QPM) contains double amounts of lysine and arginine, higher levels of tryptophan and cystein with no change in other amino acids, except lower levels of leucine. The QPM amino acid profile gives a good balance of total essential amino acids, and has an amino acid digestibility score of $67 \%$ compared to $28.5,31.0$ and $33 \%$ values for pioneer, dent and flint maize respectively (Zakadas et al., 1995). Weed infestation and low soil fertility are the most important factors constraining the production of QPM particularly in the Nigerian savanna zone where it is widely grown (Mahadi et al., 2012). Weeds compete with maize for growth resources particularly during the critical period of weed infestation which is between 3 and 6 weeks after sowing in maize thereby depressing growth, development and yield of the crop (Lagoke et al., 1991). In Nigeria, losses of up to $80 \%$ in the potential yield of maize had been attributed to unchecked weed growth throughout the crop life cycle (Lagoke et al., 1991). Methods of weed control in maize include manual method which involves hand pulling and use of hoes, mechanical method which involves use of tractors and other mechanical devices and biological methods which involves using an organism to suppress another. These methods of weed control are usually labour intensive, costly and not easily available at the right time of need or require techniques which are beyond the knowledge of local farmers. Consequently chemical method of weed control which involves the use of herbicides is an efficient, effective and economical method which can therefore serve as an alternative weed control method. 
Lombin (1987) reported low organic matter content and low cation exchange capacity as characteristic features of Nigerian soils. He further identified nitrogen and phosphorus as the most limiting nutrients in the soil.

In recent times the high cost of inorganic fertilizers and its poor distribution methods have affected its availability to resource poor farmers thereby resulting in the use of insufficient quantities at the time of need which usually contributes to low crop yields. In line with the foregoing an alternative source of crop nutrition such as by the use of cow dung manure can be considered. Cow dung manure is an important resource for crop production and soil nutrient sustainability. It provides an excellent source of organic matter and restores some essential nutrients depleted by the prevailing cropping practices (Bahman and James.1999). To restore and maintain the soil nutrient status for improved crop productivity cow dung manure application can be considered as an option provided it is applied at the right dosage and time. In view of its rich protein content, improved crop husbandry practices aimed at improving the growth and development of the crop such as adequate weed control and crop nutrition will translate to higher yield thereby boosting the production of the crop, this will enhance the nutritional status of the populace by ensuring food security and improving livelihood.

This study was undertaken with the objective of evaluating weed control treatments and cow dung manure to ascertain their influence on growth indices of QPM.

\section{MATERIALS AND METHODS}

Field trials were conducted during the 2006, 2007 and 2008 rainy seasons at the research farm of the Institute for Agricultural Research Samaru $\left(11^{\circ} 11^{\prime} \mathrm{N}\right.$ $07^{\circ} 38^{\prime} \mathrm{E}$ and 686 meters above sea level) in the Northern Guinea savanna ecological zone of Nigeria. The physico- chemical properties of the soils at the experimental sites and the cow dung manure used in the trials are presented in Tables 1 and 2 respectively. The crop variety used was SAMMAZ 14, which is late maturing with a yield potential of $5 t / h a$.

The trials consisted of factorial combinations of eight weed control treatments, which includes application of proprietary mixtures of (Atrazine + Acetochlor + Terbuthylazine at a ratio of $1: 1: 1$, Atrazine + Metolachlor at a ratio of $1: 2$ each at 3.0 and $4.0 \mathrm{~kg}$ a.i/ha, Atrazine at 4.0 and $5.0 \mathrm{~kg} \mathrm{a.i} / \mathrm{ha}$, Hoe weeded at 3 and 6 weeks after sowing and a weedy check), with four cow dung manure levels at $(0,4,8$ and $12 \mathrm{t} / \mathrm{ha}$ and the recommended NPK mineral fertilizer rate of $120 \mathrm{~kg} \mathrm{~N}, 26 \mathrm{~kg} \mathrm{P}$ and $50 \mathrm{~kg} \mathrm{~K} / \mathrm{ha}$ to serve as a check for comparison. The weed control treatments were assigned to the main plots while the fertilizer treatments were assigned to the sub-plots. The treatments were laid out in a split plot design with three replications. The gross and net plot sizes were $18 \mathrm{~m}^{2}$ and $12 \mathrm{~m}^{2}$ respectively. The experimental site was ploughed, harrowed and ridged at $75 \mathrm{~cm}$ apart. Cow dung manure was incorporated on treatment basis two weeks before planting.
The seeds were planted on the $19^{\text {th }}$ July $2006,10^{\text {th }}$ June 2007 and $16^{\text {th }}$ June 2008 . Two seeds were sown per hole manually along the ridges at an intra-row spacing of $25 \mathrm{~cm}$. After germination seedlings were thinned to one plant per stand at two weeks after sowing. Pre-emergence herbicides were applied immediately after sowing using a Cp3 knapsack sprayer set at a pressure of $2.1 \mathrm{~kg} / \mathrm{m}^{2}$. Hoe weeding was carried out at 3 and 6 weeks after sowing for the hoe weeded control in each year of the trial. Inorganic fertilizers were applied by side dressing at the rate of $120 \mathrm{~kg} \mathrm{~N}, 26 \mathrm{~kg} \mathrm{P}$ and $50 \mathrm{~kg} \mathrm{~K} / \mathrm{ha}$ to supply the inorganic fertilizer treatment plots. The $\mathrm{N}$ was applied in two split doses at 3 and 6 weeks after sowing while the $P$ and $K$ were applied at 3 weeks after sowing using NPK 15:15:15 and Urea 46\% N.

Data was collected on leaf area index, total dry matter, crop growth rate, relative growth rate, shoot lodging count and harvest index. Data collected were subjected to analysis of variance as described by Snedecor and Cochran (1967). The treatment means were separated using Duncan's multiple range test (Duncan, 1955).

\section{RESULTS}

The soils of the experimental sites were loam and moderately acidic with low $\mathrm{N}$ and $\mathrm{P}$, while the $\mathrm{Na}$ and CEC were moderate (Table 1). Result of the analyzed dry cow dung samples revealed a high concentration of macro and micro nutrients. Total nitrogen was 2.11, 1.86 and $1.97 \%$ in 2006, 2007 and 2008 respectively, available phosphorus was $0.72,0.64$ and $0.67 \%$ in 2006, 2007 and 2008 respectively, available potassium was $1.87,1.73$ and $1.82 \%$ in 2006, 2007 and 2008 respectively, percentage calcium was $0.52,0.36$ and 0.48 in 2006,2007 and 2008 respectively, magnesium $0.65,0.42$ and $0.83 \%$ in 2006, 2007 and 2008 respectively and organic carbon $18.2,26.5$ and $23.7 \%$ in 2006, 2007 and 2008 respectively (Table 2). It was observed that the manure used in the first year was richer than those used in the preceding years with the second year having the least values for each of the nutrients tested except for organic carbon which was high as indicated above and in Table 2 . The herbicide treatments and plots weeded twice produced higher leaf area index (LAI) compared to the weedy check in all the seasons and the mean. In 2006, 2008 seasons and the mean, plots treated with Atrazine + Metolachlor at $4.0 \mathrm{~kg}$ a.i/ha had the highest LAI values of $3.02,3.27$ and 3.05 respectively while in 2007 season plots treated with Atrazine + Metolachlor at $4.0 \mathrm{~kg} \mathrm{a.i} / \mathrm{ha}$, Atrazine at $5.0 \mathrm{~kg} \mathrm{a.i} / \mathrm{ha}$ and those weeded twice at 3 and 6 weeks after sowing had the highest LAI values of 2.86, 2.79 and 2.91 respectively. The weedy check plots consistently gave the least LAI values of $2.22,1.98,1.84$ and 2.01 respectively in 2006, 2007, 2008 and the mean (Table 3).

Throughout the seasons and the mean each increase in cow dung rate from $0-12 \mathrm{t} /$ ha led to a significant increase in leaf area index.

The 12t/ha treatment gave the highest LAI values which were statistically the same to the NPK fertilizer check (Table 3). 
Plots treated with Atrazine + Metolachlor at $4.0 \mathrm{~kg}$ a.i/ha and those weeded twice produced the heaviest total dry matter (TDM) of 138.0 and 140.7 grams/per plant respectively in 2006, 150.3 and 148.9 grams/plant respectively in 2008, 140.2 and 137.3 grams/plant respectively in the mean, however in 2007 season, plots treated with Atrazine + Metolachlor at $4.0 \mathrm{~kg}$ a.i/ha produced the heaviest TDM per plant which was statistically comparable to those treated with Atrazine + Acetochlor + Terbuthylazine at $4.0 \mathrm{~kg}$ a.i/ha., Atrazine + Metolachlor at $3.0 \mathrm{~kg} \mathrm{a.i} / \mathrm{ha}$ and Atrazine at $5.0 \mathrm{~kg}$ a.i/ha. The weedy check treatment consistently produced the least TDM per plant throughout the seasons and the mean (Table 3 ).

Each increase in cow dung manure from the control to $12 \mathrm{t} / \mathrm{ha}$ led to a significant increase in TDM per plant in all seasons and the mean. The $12 \mathrm{t} / \mathrm{ha}$ treatment recorded the heaviest TDM of 174.4, 153.0, 170.9 and 166.1 grams respectively in the three seasons and the mean which were comparable to the NPK treatment in 2006 and 2007 seasons (Table 3).

There was a highly significant interaction between weed control and cow dung manure treatments in 2007 season (Table 3a). Holding cow dung at 12t/ha and the NPK mineral fertilizer constant, all the weed control treatments produced similar and heavier TDM and each was superior to the weedy check and Atrazine + Acetochlor + Terbuthylazine at $3.0 \mathrm{~kg}$ a.i/ha (Table 3a).

In 2006, 2007 seasons and the mean plots treated with Atrazine + Metolachlor at $4.0 \mathrm{~kg} \mathrm{a.i} / \mathrm{ha}$ and those weeded twice recorded significantly higher crop growth rate (CGR) which were statistically similar to plots treated with Atrazine + Acetochlor + Terbuthylazine at $4.0 \mathrm{~kg}$ a.i/ha in 2007 season only, however in 2008 season the two hoe weeded recorded the highest CGR. The least CGR was by the weedy check in all the seasons and the mean (Table 4).

Each increase in cow dung from 0 to $12 \mathrm{t} / \mathrm{ha}$ led to a significant increase in CGR. The $12 \mathrm{t} /$ ha recorded the highest CGR which was statistically the same with the NPK mineral fertilizer treatment throughout the seasons and the mean, the 0 control treatment produced the least CGR (Table 4).

A significant interaction between weed control treatments and cow dung manure on crop growth rate was observed in 2006 season (Table 4). Generally with all the weed control treatments each increase in cow dung rate increased CGR of QPM. The highest crop growth rate was by application of Atrazine + Metolachlor at $4.0 \mathrm{~kg} \mathrm{a.i} / \mathrm{ha}$ and the two hoe weeded in conjunction with NPK fertilizer treatment (Table 4a). In 2006 season, plots that received Atrazine + Metolachlor at $3.0 \mathrm{~kg}$ a.i/ha resulted in significantly higher relative growth rate (RGR) than the weedy check but statistically at par to all other weed control treatments.

In 2007, Atrazine + Metolachlor at $4.0 \mathrm{~kg} \mathrm{a.i/ha}$ and Atrazine at $5.0 \mathrm{~kg}$ a.i/ha gave significantly higher RGR than the other treatments but were statistically at par to the two hoe weeded. However, in 2008 season, application of Atrazine + Metolachlor at both rates gave significantly higher RGR than all the other weed control treatments; while in the mean data, Atrazine + Metolachlor at $3.0 \mathrm{~kg}$ a.i/ha significantly had higher RGR than Atrazine + Acetochlor + Terbuthylazine at $3.0 \mathrm{~kg} \mathrm{a.i} / \mathrm{ha}$, Atrazine at $4.0 \mathrm{~kg} \mathrm{a.i} / \mathrm{ha}$ and the weedy check which had the lowest RGR throughout the seasons and the mean.

The RGR increased with increasing cow dung from 0 $12 \mathrm{t} / \mathrm{ha}$ in 2007, 2008 and the mean and from 0 4t/ha in 2006 season (Table 4).

Shoot lodging count was significantly increased by application of Atrazine + Acetochlor + Terbuthylazine and Atrazine Metolachlor each at $4.0 \mathrm{~kg}$ a.i/ha in 2006 season, while in 2007 season and the mean, application of Atrazine + Acetochlor + Terbuthylazine at $4.0 \mathrm{~kg}$ a.i/ha led to higher shoot lodging count. However, in 2008 application of Atrazine Metolachlor at $4.0 \mathrm{~kg}$ a.i/ha had the highest shoot lodging count which was statistically comparable to Atrazine at 5.0 $\mathrm{kg} \mathrm{a.i/ha} \mathrm{(Table} \mathrm{5).} \mathrm{Each} \mathrm{increase} \mathrm{in} \mathrm{cowdung} \mathrm{rate}$ from $0-12 t / h a$ led to a significant increase in shoot lodging count in 2007 season and the mean. However, in 2006 and 2008 seasons each increase in cow dung rate from $0-4 \mathrm{t} / \mathrm{ha}$ and $8-12 \mathrm{t} / \mathrm{ha}$ led to a significant increase in shoot lodging count. The $12 \mathrm{t} /$ ha treatment had the highest shoot lodging count which was statistically the same with the NPK fertilizer treatment in 2006, 2008 seasons and the mean (Table 5).

All weed control treatments with the exception of Atrazine at $4.0 \mathrm{~kg} \mathrm{a.i} / \mathrm{ha}$ in 2007 season and the mean, and Atrazine at both rates in 2008, Atrazine + Acetochlor + Terbuthylazine at $3.0 \mathrm{~kg} \mathrm{a.i/ha}$ in the mean and the weedy check in all the seasons resulted in significantly higher harvest index of QPM.

In 2006 and 2008 seasons, each increase in cow dung rate from $0-12 t /$ ha led to a significant increase in harvest index of QPM while in 2007 season and the mean each increase in cow dung manure from $4-12 \mathrm{t}$ led to a significant increase in harvest index of QPM. The 12t/ha treatment and the NPK fertilizer treatment recorded the highest harvest index of $0.47,0.37,0.45$ and 0.43 respectively for the $12 \mathrm{t} / \mathrm{ha}$ treatment across the years and the mean while harvest index values of $0.45,0.38,0.45$ and 0.43 respectively were recorded across the years and the mean in the NPK treated plots (Table 5)

\section{DISCUSSION}

The growth indices of QPM such as leaf area index, total dry matter, crop growth rate and relative growth rate were significantly $(P>0.05)$ affected by the weed control treatments. Plots treated with Atrazine + Metolachlor at $4.0 \mathrm{~kg} \mathrm{a.i} / \mathrm{ha}$ throughout the seasons and those weeded twice in 2006, 2008 and the mean resulted in significantly ( $P>0.05$ ) higher total dry matter of $138.0,132.5$, and150.3 grams per plant in plots treated with Atrazine + Metolachlor at $4.0 \mathrm{~kg}$ a.i/ha, across the seasons and 140.7, 148.9 and 137.3 grams per plant in plots weeded twice in both seasons and the mean, while the weedy check produced the least total dry matter of QPM. 
The higher dry matter recorded by these treatments could be attributed to less weed competition resulting in better use of available growth factors for maximum photosynthetic activities (Rasheed et a/ 2003). This is in line with the findings of Adekpe (2004) who reported higher total dry matter of garlic with two hoe weeded control and $2.0 \mathrm{~kg}$ a.i/ha of Oxadiazon. Leaf area index of QPM was also significantly increased by the application of Atrazine + Metolachlor at $4.0 \mathrm{~kg}$ a.i/ha throughout the season, Atrazine at $5.0 \mathrm{~kg} \mathrm{a.i} / \mathrm{ha}$ and two hoe weeded in 2006 season. Crops are known to attain better canopy with higher number of leaves per plant in a less weed competitive situation than in a weedy environment (Lagoke et al., 1991). Atrazine + Metolachlor is a mixture of two different herbicides, Atrazine is a broad leaf weed killer while Metolachlor is a grass killer, this might have indefinitely increased the spectrum and efficacy of weed control. Throughout the seasons the herbicide treatments and hoe weeded resulted in higher crop growth rate and relative growth rate of QPM than the weedy check. This could be due to good weed control which allowed crops to develop larger leaves and consequently higher light interception for increased dry matter accumulation per plant per unit area of land. Similar observation was made by Ishaya (2004), who reported lower crop growth rate and relative growth rate by crops in the weedy check and lower rates of oxadiazon.

Application of cow dung manure at 8 and 12t/ha significantly increased total dry matter, leaf area index, crop growth rate, relative growth rates, shoot lodging count and harvest index of QPM. The increase of these parameters as a result of the application of cow dung manure improved availability of nutrients in the soil that were necessary for growth and development in crops (Anon, 2007b). Cow dung manure has also been reported to greatly improve water holding capacity, soil aeration, soil structure, nutrient retention and microbial activity in the soil (Anon, 2007 a).

\section{CONCLUSION}

The study concluded that application of Atrazine + Metolachlor at $4.0 \mathrm{~kg} \mathrm{a.i} / \mathrm{ha}$ and cow dung manure at $12 \mathrm{t} / \mathrm{ha}$ adequately controlled weeds and provided nutrients which increased growth indices and development of Quality Protein Maize.

\begin{tabular}{|c|c|c|c|}
\hline Composition & $\begin{array}{l}2006 \\
0-15 \mathrm{~cm}\end{array}$ & $\begin{array}{l}2007 \\
0-15 \mathrm{~cm}\end{array}$ & $\begin{array}{l}2008 \\
0-15 \mathrm{~cm}\end{array}$ \\
\hline \multicolumn{4}{|l|}{ Physical Properties } \\
\hline Sand (\%) & 43 & 46 & 41 \\
\hline Silt (\%) & 38 & 36 & 40 \\
\hline Clay (\%) & 19 & 18 & 19 \\
\hline Textural class & Loam & Loam & Loam \\
\hline \multicolumn{4}{|l|}{ Chemical properties } \\
\hline $\mathrm{pH}$ in $\mathrm{H}_{2} \mathrm{O}(1: 2: 5)$ & 5.6 & 5.8 & 5.7 \\
\hline $\mathrm{pH}$ in $0.01 \mathrm{~m} \mathrm{CaCl} 2(1: 2: 5)$ & 5.4 & 5.7 & 5.3 \\
\hline Organic Carbon $(\mathrm{g} / \mathrm{kg})$ & 0.63 & 0.52 & 0.48 \\
\hline Total Nitrogen $(\mathrm{g} / \mathrm{kg})$ & 0.61 & 0.36 & 0.68 \\
\hline Available Phosphorus (meq/kg) & 13.4 & 9.8 & 11.3 \\
\hline \multicolumn{4}{|c|}{ Exchangeable Cations (Cmol/kg soil) } \\
\hline Calcium & 1.20 & 1.00 & 1.40 \\
\hline Sodium & 1.00 & 1.00 & 1.20 \\
\hline Potassium & 0.58 & 0.96 & 0.62 \\
\hline Magnesium & 0.64 & 0.82 & 0.67 \\
\hline C.E.C & 5.80 & 5.60 & 5.80 \\
\hline
\end{tabular}

Table 2: Chemical Properties of Cow dung Manure Samples

\begin{tabular}{llll}
\hline Chemical composition & $\mathbf{2 0 0 6}$ & $\mathbf{2 0 0 7}$ & $\mathbf{2 0 0 8}$ \\
\hline Total nitrogen (\%) & 2.11 & 1.86 & 1.97 \\
Available phosphorus (\%) & 0.72 & 0.64 & 0.67 \\
Potassium (\%) & 1.87 & 1.73 & 1.82 \\
Calcium (\%) & 0.52 & 0.36 & 0.48 \\
Magnesium (\%) & 0.65 & 0.42 & 0.83 \\
Organic carbon (\%) & 18.2 & 26.5 & 23.7 \\
\hline
\end{tabular}


Bajopas Volume 5 Number 2 December, 2012

Table 3: Effect of weed control treatments and cow dung manure on leaf area index and total dry matter of QPM at Samaru during 2006,2007 and 2008 rainy seasons and the mean.

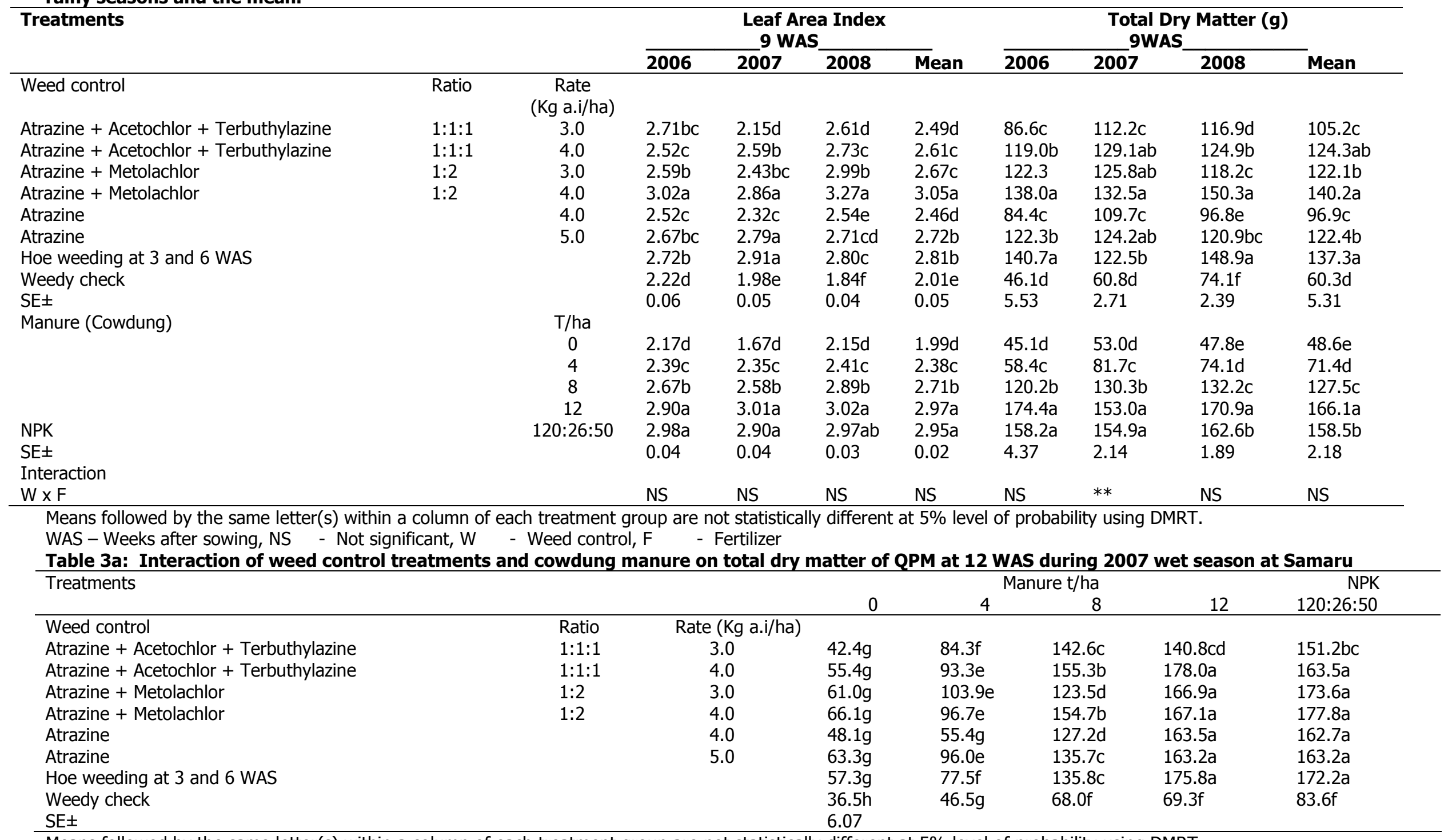

Means followed by the same letter(s) within a column of each treatment group are not statistically different at 5\% level of probability using DMRT. 
Bajopas Volume 5 Number 2 December, 2012

Table 4: Effect of weed control treatments and cowdung manure on crop growth rate and relative growth rate of QPM at Samaru during 2006, 2007 and 2008 rainy seasons and the mean.

\begin{tabular}{|c|c|c|c|c|c|c|c|c|c|c|}
\hline \multirow[t]{2}{*}{ Treatments } & & & \multicolumn{4}{|c|}{ Crop Growth Rate( 6-9 WAS) } & \multicolumn{4}{|c|}{ Relative Growth Rate(9WAS) } \\
\hline & & & 2006 & 2007 & 2008 & Mean & 2006 & 2007 & 2008 & Mean \\
\hline Weed control & Ratio & Rate (Kg a.i/ha) & & & & & & & & \\
\hline Atrazine + Acetochlor + Terbuthylazine & $1: 1: 1$ & 3.0 & $6.6 c$ & $7.4 d$ & $5.3 e$ & $6.4 d$ & $0.12 \mathrm{ab}$ & $0.15 c$ & $0.17 c$ & $0.15 b$ \\
\hline Atrazine + Acetochlor + Terbuthylazine & $1: 1: 1$ & 4.0 & $8.5 b$ & $11.1 \mathrm{a}$ & $7.9 \mathrm{~d}$ & $9.1 b$ & $0.14 a b$ & $0.17 \mathrm{~b}$ & $0.19 b$ & $0.17 a b c$ \\
\hline Atrazine + Metolachlor & $1: 2$ & 3.0 & $6.8 \mathrm{c}$ & $9.2 \mathrm{~b}$ & $10.2 c$ & $8.7 \mathrm{~b}$ & $0.20 \mathrm{a}$ & $0.15 c$ & $0.21 a$ & $0.19 a$ \\
\hline Atrazine + Metolachlor & $1: 2$ & 4.0 & $10.9 a$ & $11.0 \mathrm{a}$ & $11.5 b$ & $11.1 \mathrm{a}$ & $0.12 a b$ & $0.20 \mathrm{a}$ & $0.21 a$ & $0.18 \mathrm{ab}$ \\
\hline Atrazine & & 4.0 & $7.2 \mathrm{c}$ & $8.2 \mathrm{c}$ & $7.3 d$ & $7.5 c$ & $0.11 \mathrm{ab}$ & $0.14 \mathrm{c}$ & $0.16 c$ & $0.14 \mathrm{c}$ \\
\hline Atrazine & & 5.0 & $8.7 \mathrm{~b}$ & $9.6 \mathrm{~b}$ & $10.1 \mathrm{c}$ & $9.4 b$ & $0.19 a b$ & $0.20 \mathrm{a}$ & $0.16 c$ & $0.18 a b$ \\
\hline Hoe weeding at 3 and 6 WAS & & & $11.1 \mathrm{a}$ & $11.6 a$ & $12.8 \mathrm{a}$ & $11.8 \mathrm{a}$ & $0.13 a b$ & $0.19 a b$ & $0.16 c$ & $0.16 a b c$ \\
\hline Weedy check & & & $3.9 \mathrm{~d}$ & $4.3 e$ & $4.0 f$ & $4.0 \mathrm{e}$ & $0.08 \mathrm{~b}$ & $0.10 d$ & $0.09 d$ & $0.09 d$ \\
\hline SE \pm & & & 0.29 & 0.25 & 0.26 & 0.27 & 0.03 & 0.09 & 0.25 & 0.02 \\
\hline \multirow[t]{5}{*}{ Manure (Cowdung) } & & T/ha & & & & & & & & \\
\hline & & 0 & $2.2 d$ & $2.6 \mathrm{~d}$ & $2.5 d$ & $2.4 d$ & $0.06 \mathrm{~b}$ & $0.09 d$ & $0.10 \mathrm{e}$ & $0.09 d$ \\
\hline & & 4 & $5.5 c$ & $4.4 \mathrm{c}$ & $5.2 \mathrm{C}$ & $5.0 \mathrm{c}$ & $0.14 a b$ & $0.13 c$ & $0.13 d$ & $0.13 c$ \\
\hline & & 8 & $8.2 b$ & $10.1 b$ & $8.4 \mathrm{~b}$ & $8.9 \mathrm{~b}$ & $0.13 a b$ & $0.19 b$ & $0.19 \mathrm{c}$ & $0.17 \mathrm{~b}$ \\
\hline & & 12 & $11.7 a$ & $14.1 \mathrm{a}$ & $13.5 \mathrm{a}$ & $13.1 \mathrm{a}$ & $0.17 a$ & $0.21 a$ & $0.22 a$ & $0.20 a$ \\
\hline NPK & & $120: 26: 50$ & $12.2 \mathrm{a}$ & $14.0 \mathrm{a}$ & $13.6 a$ & $13.2 \mathrm{a}$ & $0.20 a$ & $0.18 b$ & $0.20 \mathrm{~b}$ & $0.19 a b$ \\
\hline SE \pm & & & 0.23 & 0.28 & 0.20 & 0.19 & 0.02 & 0.12 & 0.15 & 0.01 \\
\hline \multicolumn{11}{|l|}{ Interaction } \\
\hline$W \times F$ & & & $*$ & NS & NS & NS & NS & NS & NS & NS \\
\hline
\end{tabular}

Means followed by the same letter(s) within a column of each treatment group are not statistically different at 5\% level of probability using DMRT.

WAS - Weeks after sowing, NS - Not significant, W - Weed control, F - Fertilizer

Table 4a: Interaction of weed control treatments and cowdung manure on crop growth rate of QPM at 12WAS during 2006 wet season at Samara Treatments

20:26:50

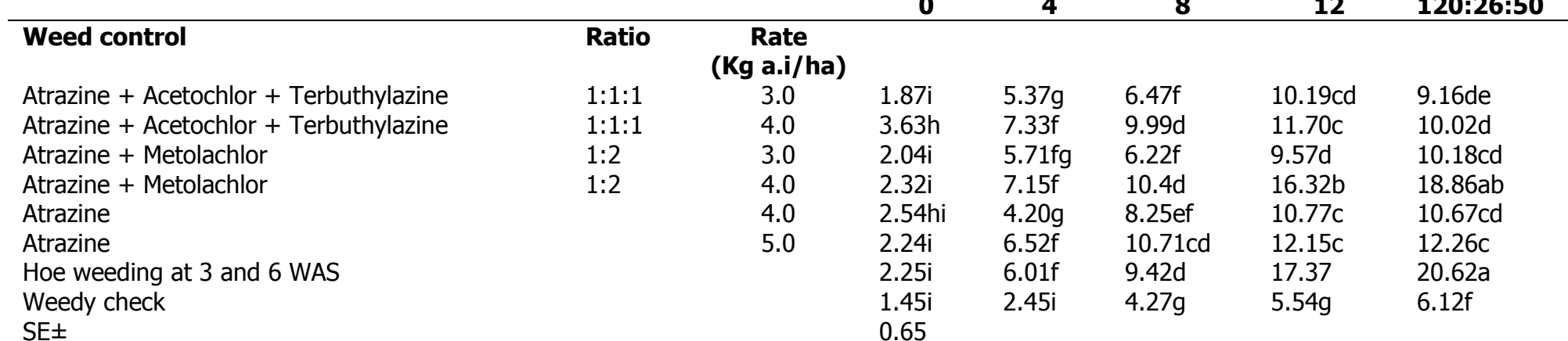

Means followed by the same letter(s) within a column of each treatment group are not statistically different at $5 \%$ level of probability using DMRT. 
Bajopas Volume 5 Number 2 December, 2012

Table 5: Effect of weed control treatments and cowdung manure on shoot lodging count and harvest index of QPM at Samaru during 2006, 2007 and 2008 rainy seasons and the mean.

\begin{tabular}{|c|c|c|c|c|c|c|c|c|c|c|}
\hline \multirow[t]{2}{*}{ Treatments } & & & \multicolumn{4}{|c|}{ Shoot Lodging count } & \multicolumn{3}{|c|}{ Harvest Index } & \multirow[b]{2}{*}{ Mean } \\
\hline & & & 2006 & 2007 & 2008 & Mean & 2006 & 2007 & 2008 & \\
\hline Weed control & Ratio & $\begin{array}{c}\text { Rate } \\
\text { (Kg a.i/ha) }\end{array}$ & & & & & & & & \\
\hline Atrazine + Acetochlor + Terbuthylazine & $1: 1: 1$ & 3.0 & $6.6 c$ & $7.6 \mathrm{c}$ & $3.5 \mathrm{c}$ & $5.9 \mathrm{~d}$ & $0.37 a$ & $0.33 a b$ & $0.40 \mathrm{ab}$ & $0.29 b$ \\
\hline Atrazine + Acetochlor + Terbuthylazine & $1: 1: 1$ & 4.0 & $12.3 a$ & $10.0 \mathrm{a}$ & $4.7 \mathrm{~b}$ & $9.0 a$ & $0.40 a$ & $0.32 \mathrm{ab}$ & $0.41 \mathrm{ab}$ & $0.37 a b$ \\
\hline Atrazine + Metolachlor & $1: 2$ & 3.0 & $10.2 b$ & $4.8 \mathrm{~d}$ & $4.5 b$ & $6.5 \mathrm{~cd}$ & $0.39 a$ & $0.31 a b$ & $0.43 a$ & $0.37 a b$ \\
\hline Atrazine + Metolachlor & $1: 2$ & 4.0 & $11.9 a$ & $6.5 c$ & $6.0 a$ & $8.1 \mathrm{~b}$ & $0.42 a$ & $0.36 a$ & $0.44 a$ & $0.41 a$ \\
\hline Atrazine & & 4.0 & $7.2 \mathrm{c}$ & $8.8 \mathrm{~b}$ & $4.1 \mathrm{~b}$ & $6.7 \mathrm{c}$ & $0.37 a$ & $0.26 \mathrm{~b}$ & $0.32 \mathrm{c}$ & $0.31 \mathrm{c}$ \\
\hline Atrazine & & 5.0 & $7.3 c$ & $5.9 \mathrm{c}$ & $5.0 \mathrm{ab}$ & $6.0 \mathrm{~d}$ & $0.41 a$ & $0.32 \mathrm{ab}$ & $0.36 \mathrm{~b}$ & $0.35 \mathrm{ab}$ \\
\hline Hoe weeding at 3 and 6 WAS & & & $1.5 \mathrm{~d}$ & $1.6 \mathrm{f}$ & $1.0 \mathrm{~d}$ & $1.4 \mathrm{e}$ & $0.40 \mathrm{a}$ & $0.20 \mathrm{ab}$ & $0.42 \mathrm{a}$ & $0.34 \mathrm{ab}$ \\
\hline Weedy check & & & $2.0 d$ & $2.2 \mathrm{e}$ & $1.6 \mathrm{~d}$ & $1.9 \mathrm{e}$ & $0.30 \mathrm{~b}$ & $0.18 c$ & $0.15 \mathrm{e}$ & $0.21 d$ \\
\hline SE \pm & & & 0.36 & 0.29 & 0.44 & 0.36 & 0.01 & 0.01 & 0.01 & 0.01 \\
\hline \multirow[t]{5}{*}{ Manure (Cowdung) } & & T/ha & & & & & & & & \\
\hline & & 0 & $6.0 \mathrm{c}$ & $3.0 \mathrm{e}$ & $1.7 \mathrm{c}$ & $3.5 d$ & $0.26 \mathrm{~d}$ & $0.20 c$ & $0.21 d$ & $0.22 \mathrm{c}$ \\
\hline & & 4 & $6.9 b$ & $4.5 d$ & $2.2 b$ & $4.5 c$ & $0.30 \mathrm{c}$ & $0.17 c$ & $0.26 c$ & $0.24 \mathrm{c}$ \\
\hline & & 8 & $7.0 \mathrm{~b}$ & $6.3 c$ & $2.6 \mathrm{~b}$ & $5.3 b$ & $0.43 b$ & $0.27 b$ & $0.37 b$ & $0.36 \mathrm{~b}$ \\
\hline & & 12 & $8.7 a$ & $8.4 a$ & $6.7 a$ & $7.6 a$ & $0.47 a$ & $0.37 a$ & $0.45 a$ & $0.43 a$ \\
\hline NPK & & $120: 26: 50$ & $8.3 a$ & $7.4 b$ & $6.8 a$ & $7.5 a$ & $0.45 a$ & $0.38 a$ & $0.45 a$ & $0.43 a$ \\
\hline SE \pm & & & 0.28 & 0.23 & 0.35 & 0.28 & 0.01 & 0.01 & 0.01 & 0.01 \\
\hline \multicolumn{11}{|l|}{ Interaction } \\
\hline$W \times F$ & & & NS & NS & NS & NS & NS & NS & NS & NS \\
\hline
\end{tabular}

Means followed by the same letter(s) within a column of each treatment group are not statistically different at 5\% level of probability using DMRT.

WAS - Weeks after sowing

NS - Not significant

W - Weed contro

F - Fertilizer 


\section{REFERENCES}

Adekpe D.I., Shinggu C.P., Adesanya A.A. and Bitrus C.T. (2004): Effect of pre- emergence herbicides on the performance of roselle (Hibiscus Sabdariffa) at Samaru Zaria. A paper presented at the $22^{\text {nd }}$ Annual Conference of the Horticultural Society of Nigeria (HORTSON) held at Daula Hotel, Kano $4^{\text {th }}-9^{\text {th }}$ July 2004.

Anonymous (2007a): Effects of organic and inorganic nutrient sources on soil mineral nitrogen and maize yield in western Kenya. http:/www. a gnet org.

Anonymous (2007b): Managing soil fertility for vegetable production.http:/www. agnet org.

Badu-Apraku, B.; Menkir, A.; Fakorede, M.A.B.; Fanten Lum. A and K. Obeng-Antwi (2006): Multivariate analysis of the genetic diversity of forty-seven striga resistant tropical early maturing maize inbred lines. Maydica 51: $551-559$.

Bahman, E and James, F.P. (1999): Composted and non composted manure application to conventional and no tillage systems in corn yield and nitrogen uptake. Agronomy journal 91: 819pp

Duncan D.B. (1955): Multiple range and Multiple F tests. Biometrics $11: 1-42$

FAO (2008): Bulletin of statistics. FAO. Stat.org.

Ishaya, D.B. (2004): Evaluation of weed control treatments and rice varieties on weeds, growth and yield of rice/sorghum mixture. Unpublished Ph. D seminar paper, Department of Agronomy, Ahmadu Bello University, Zaria. 34pp.

Kamara. A.Y. and Sanginga. N. (2001): Balance nutrient management for intensified maizebased systems in the Northern guinea savanna of West-Africa. In: Proceedings of the National Quality Protein Maize Production Workshop $4^{\text {th }}-5^{\text {th }}$ September 2001 at the Institute for Agricultural Research Conference Hall A.B.U. Zaria Pp. $17-24$.

Lagoke, S.T.O., Shebayan, J.A.Y. and Iwuafor, E.N.O. (1991): Survey of striga problem on farm testing of integrated striga control methods in maize, sorghum and cowpea in Nigeria. $171 \mathrm{pp}$.
Lombin, G. (1987): Towards efficiency of fertilizer use and development in Nigeria. Proceedings of the National Fertilizer Seminar, Port Harcourt. Pp $106-123$.

Mahadi,M.A.,Dadari,S.A., Tanimu,B., Kuchinda, N.C., and

Shinggu,C.P.(2012) Influence of weed control treatments and cowdung manure on growth and development of quality protein maize. Biological and environmental science journal for the tropics 9 (1) 168-174

Snedecor,G.W. and Cochran W.G (1967): Statistical Methods, $6^{\text {th }}$ edition. IOWA State University Press. U.S.A. 456pp

Zakadas C.G., Yu-z, R.I. Hamilton P.L Pattison and N.G.W. Rose. (1995): Comparison between the protein qualities of northern adapted cultivars of common maize and quality protein maize, Journal of Agric. Food Chemistry. Washington D.C., American chemistry society 43 (1) 84-93. 